\title{
Sickness certification of workers compensation claimants by general practitioners in Victoria, 2003-2010
}

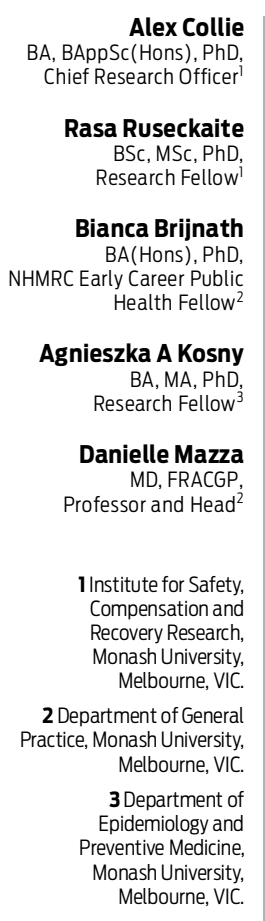

alex.collie@monash.edu

MJA 2013; 199: 480-483 doi: 10.5694/mjal3.10508

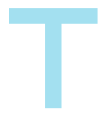

he past decade has seen substantial health policy reform aimed at increasing labour force participation by injured and ill workers. Underpinning these reforms is a growing body of evidence showing that safe work is good for health ${ }^{1,2}$ and that return to work (RTW) after injury or illness can promote recovery. ${ }^{3,4}$ General practitioners play a key role in the RTW process, being the first point of contact with the health care system for many injured workers, and the main "gatekeepers" to workers compensation and disability benefits.

Understanding the behaviour and attitudes of GPs towards injured and ill workers is an area of growing interest among primary care and work injury researchers. To date, no Australian data on this have been published. Overseas research has shown that, despite most GPs believing that work is generally beneficial for health, there are divergent views among GPs regarding their role in RTW processes. ${ }^{5}$ Some believe that their focus should be on the medical recovery of the worker, but others acknowledge their role in RTW processes. ${ }^{6}$ Many GPs do not consider RTW processes and the work-health nexus to be part of their role, ${ }^{7}$ and some would prefer to have no role in sickness certification. ${ }^{8}$

Evidence that GP sickness certification practices vary according to worker characteristics is growing. A common finding is that GPs are more likely to certify workers with mental health conditions (MHCs) as unfit for work than those with physical conditions. ${ }^{9,10}$ Risk factors for longer duration of work incapacity include older age, social deprivation, and presence of mild and severe MHCs. ${ }^{11}$ Other factors which influence GP attitudes about managing RTW include weak doctor-patient relationships, pressure on consultation time, fears for personal safety, limited knowledge about the patient's workplace, and the administrative burden of dealing with the compensation system. ${ }^{8,12-14}$

\begin{abstract}
Objective: To examine patterns of the sickness certification of workers compensation claimants by general practitioners in Victoria, Australia, by nature of injury or illness.

Design, setting and patients: Retrospective analysis of Victorian workers compensation data for all injured and ill workers with an accepted workers compensation claim between 2003 and 2010.

Main outcome measures: Type (unfit for work, alternative duties, or fit for work) and duration of initial medical certificates relating to workers compensation claims that were issued by GPs, in six categories of injury and illness.

Results: Of 124424 initial medical certificates issued by GPs, $74.1 \%$ recommended that workers were unfit for work and $22.8 \%$ recommended alternative duties. Unfit-for-work certificates were issued to $94.1 \%$ of workers with mental health conditions, $81.3 \%$ of those with fractures, $79.1 \%$ of those with other traumatic injuries, $77.6 \%$ of those with back pain and strains, $68.0 \%$ of those with musculoskeletal conditions and $53.0 \%$ of those with other diseases. Alternative-duties certificates were significantly longer in duration than unfit-for-work certificates in all injury and illness categories $(P<0.001)$ but certificates for workers with musculoskeletal injuries and diseases, back pain and strains and other traumatic injuries were of lesser duration than those for workers with fractures, mental health conditions and other diseases.

Conclusion: The high proportion of medical certificates recommending complete absence from work presents major challenges in terms of return to work, labour force productivity, the viability of the compensation system, and long-term social and economic development. There is substantial variation in the type and duration of medical certificates issued by GPs. People with mental health conditions are unlikely to receive a certificate recommending alternative duties. Further research is required to understand GP certification behaviour.
\end{abstract}

Much of the research on sickness certification practices has been conducted in discrete clusters of primary care practices in Europe. Certification data can also be obtained from jurisdiction-level databases, which are held by some workers compensation authorities. These have the advantages of population-based data capture and a method for verifying the work-relatedness of workers' conditions (because only claims for workrelated injury and illness are accepted).

We examined patterns of sickness certification of injured and ill workers by GPs in the state of Victoria, Australia, over an 8-year period.

\section{Methods}

Victoria had a working population of about 2.8 million in June 2011. ${ }^{15}$ Employers are required to maintain workers compensation insurance through the Victorian WorkCover
Authority (VWA) unless they are able to self-insure or obtain insurance through the national workers compensation scheme, or if they are sole traders. All injuries and illnesses that exceed the pecuniary threshold for health care expenses or have required more than 10 days work absence are required to be lodged with the VWA via one of six private insurers.

The Victorian workers compensation system requires production of a medical certificate to accept a compensation claim. Certificates can be submitted by GPs or by hospitalbased medical practitioners; they include the practitioner's recommendation regarding fitness to work, and start and end dates. Initial certificates are handwritten and provided to the injured worker's employer, who submits the certificate to the insurer. Subsequent certificates can be provided directly to the insurer and the employer. The insurer enters certificate data into a standardised data- 
1 Workers compensation claimant characteristics, numbers of initial medical certificates issued to workers by general practitioners and rates of sickness certification, by certificate type and injury and illness category, Victoria, 2003-2010

Certificate type

\begin{tabular}{|c|c|c|c|c|c|c|c|c|c|c|}
\hline \multirow[b]{2}{*}{$\begin{array}{l}\text { Injury and illness } \\
\text { category }\end{array}$} & \multicolumn{2}{|c|}{ Workers } & \multicolumn{2}{|c|}{ Total certificates } & \multicolumn{2}{|c|}{ Unfit for work } & \multicolumn{2}{|c|}{ Alternative duties } & \multicolumn{2}{|c|}{ Fit for work } \\
\hline & $\begin{array}{l}\text { No. (\%) } \\
\text { of men }\end{array}$ & $\begin{array}{c}\text { Mean } \\
\text { (SD) age } \\
\text { at onset, } \\
\text { years }\end{array}$ & $\begin{array}{l}\text { No. of } \\
\text { certificates } \\
\text { (\% of all } \\
\text { certificates) }\end{array}$ & $\begin{array}{c}\text { Rate per } \\
1000 \text { workers } \\
(95 \% \mathrm{Cl})\end{array}$ & $\begin{array}{l}\text { No. of } \\
\text { certificates } \\
\text { (\% within } \\
\text { category) }\end{array}$ & $\begin{array}{c}\text { Rate per } \\
1000 \text { workers } \\
(95 \% \mathrm{Cl})\end{array}$ & $\begin{array}{l}\text { No. of } \\
\text { certificates } \\
\text { (\% within } \\
\text { category) }\end{array}$ & $\begin{array}{c}\text { Rate per } \\
1000 \text { workers } \\
(95 \% \mathrm{Cl})\end{array}$ & $\begin{array}{l}\text { No. of } \\
\text { certificates } \\
\text { (\% within } \\
\text { category) }\end{array}$ & $\begin{array}{c}\text { Rate per } \\
1000 \text { workers } \\
(95 \% \mathrm{Cl})\end{array}$ \\
\hline $\begin{array}{l}\text { Fractures } \\
(n=12102)\end{array}$ & $\begin{array}{c}8668 \\
(71.6 \%)\end{array}$ & $\begin{array}{l}40.9 \\
(13.1)\end{array}$ & $\begin{array}{l}12102 \\
(9.7 \%)\end{array}$ & $\begin{array}{c}0.83 \\
(0.81-0.85)\end{array}$ & $\begin{array}{c}9838 \\
(81.3 \%)\end{array}$ & $\begin{array}{c}0.68 \\
(0.66-0.69)\end{array}$ & $\begin{array}{c}2051 \\
(16.9 \%)\end{array}$ & $\begin{array}{c}0.14 \\
(0.13-0.15)\end{array}$ & $\begin{array}{c}213 \\
(1.8 \%)\end{array}$ & $\begin{array}{c}0.014 \\
(0.012-0.016)\end{array}$ \\
\hline $\begin{array}{l}\text { Musculoskeletal } \\
\text { injuries and diseases } \\
(n=50 \text { 052) }\end{array}$ & $\begin{array}{c}31490 \\
(62.9 \%)\end{array}$ & $\begin{array}{l}42.8 \\
(11.5)\end{array}$ & $\begin{array}{c}50052 \\
(40.2 \%)\end{array}$ & $\begin{array}{c}3.45 \\
(3.41-3.48)\end{array}$ & $\begin{array}{c}34055 \\
(68.0 \%)\end{array}$ & $\begin{array}{c}2.35 \\
(2.32-2.37)\end{array}$ & $\begin{array}{c}14134 \\
(28.2 \%)\end{array}$ & $\begin{array}{c}0.97 \\
(0.96-0.99)\end{array}$ & $\begin{array}{l}1863 \\
(3.7 \%)\end{array}$ & $\begin{array}{c}0.13 \\
(0.12-0.14)\end{array}$ \\
\hline $\begin{array}{l}\text { Other traumatic injuries } \\
(n=19467)\end{array}$ & $\begin{array}{c}14835 \\
(76.2 \%)\end{array}$ & $\begin{array}{l}38.3 \\
(13.2)\end{array}$ & $\begin{array}{c}19467 \\
(15.6 \%)\end{array}$ & $\begin{array}{c}1.34 \\
(1.32-1.36)\end{array}$ & $\begin{array}{c}15401 \\
(79.1 \%)\end{array}$ & $\begin{array}{c}1.06 \\
(1.04-1.07)\end{array}$ & $\begin{array}{c}3414 \\
(17.5 \%)\end{array}$ & $\begin{array}{c}0.24 \\
(0.22-0.25)\end{array}$ & $\begin{array}{c}652 \\
(3.3 \%)\end{array}$ & $\begin{array}{c}0.045 \\
(0.041-0.048)\end{array}$ \\
\hline $\begin{array}{l}\text { Back pain and strains } \\
(n=20388)\end{array}$ & $\begin{array}{c}12831 \\
(62.9 \%)\end{array}$ & $\begin{array}{l}40.8 \\
(11.6)\end{array}$ & $\begin{array}{l}20388 \\
(16.4 \%)\end{array}$ & $\begin{array}{c}1.40 \\
(1.38-1.42)\end{array}$ & $\begin{array}{c}15816 \\
(77.6 \%)\end{array}$ & $\begin{array}{c}1.09 \\
(1.07-1.11)\end{array}$ & $\begin{array}{c}4218 \\
(20.7 \%)\end{array}$ & $\begin{array}{c}0.29 \\
(0.28-0.30)\end{array}$ & $\begin{array}{c}354 \\
(1.7 \%)\end{array}$ & $\begin{array}{c}0.024 \\
(0.022-0.027)\end{array}$ \\
\hline $\begin{array}{l}\text { Mental health } \\
\text { conditions }(n=12663)\end{array}$ & $\begin{array}{c}5416 \\
(42.8 \%)\end{array}$ & $\begin{array}{c}43.4 \\
(10.3)\end{array}$ & $\begin{array}{c}12663 \\
(10.2 \%)\end{array}$ & $\begin{array}{c}0.87 \\
(0.85-0.88)\end{array}$ & $\begin{array}{c}11911 \\
(94.1 \%)\end{array}$ & $\begin{array}{c}0.82 \\
(0.80-0.84)\end{array}$ & $\begin{array}{c}610 \\
(4.8 \%)\end{array}$ & $\begin{array}{c}0.040 \\
(0.038-0.045)\end{array}$ & $\begin{array}{l}142 \\
(1.1 \%)\end{array}$ & $\begin{array}{c}0.009 \\
(0.008-0.011)\end{array}$ \\
\hline $\begin{array}{l}\text { Other diseases } \\
(n=9752)\end{array}$ & $\begin{array}{c}7730 \\
(79.3 \%)\end{array}$ & $\begin{array}{l}44.2 \\
(11.5)\end{array}$ & $\begin{array}{c}9752 \\
(7.8 \%)\end{array}$ & $\begin{array}{c}0.67 \\
(0.65-0.69)\end{array}$ & $\begin{array}{c}5172 \\
(53.0 \%)\end{array}$ & $\begin{array}{c}0.36 \\
(0.35-0.37)\end{array}$ & $\begin{array}{c}3889 \\
(39.9 \%)\end{array}$ & $\begin{array}{c}0.27 \\
(0.25-0.28)\end{array}$ & $\begin{array}{c}691 \\
(7.1 \%)\end{array}$ & $\begin{array}{c}0.047 \\
(0.044-0.051)\end{array}$ \\
\hline $\begin{array}{l}\text { Total } \\
(n=124424)\end{array}$ & $\begin{array}{l}80970 \\
(65.1 \%)\end{array}$ & $\begin{array}{l}41.8 \\
(11.9)\end{array}$ & $\begin{array}{l}124424 \\
(100 \%)\end{array}$ & $\begin{array}{c}8.57 \\
(8.52-8.62)\end{array}$ & $\begin{array}{c}92193 \\
(74.1 \%)\end{array}$ & $\begin{array}{c}6.35 \\
(6.31-6.39)\end{array}$ & $\begin{array}{c}28316 \\
(22.8 \%)\end{array}$ & $\begin{array}{c}1.95 \\
(1.92-1.97)\end{array}$ & $\begin{array}{l}3915 \\
(3.1 \%)\end{array}$ & $\begin{array}{c}0.27 \\
(0.26-0.28)\end{array}$ \\
\hline
\end{tabular}

base. This information is transferred to the VWA with other claim information, enabling statewide capture of medical certification data.

There are statutory limits for the duration of certificates which state that a patient is unfit for work; these are defined in Victorian workers compensation regulations. An initial medical certificate for a workers compensation claim can be for up to 14 days. Subsequent certificates can be for up to 28 days, unless special conditions exist.

We accessed the Compensation Research Database, which was established at the Institute for Safety, Compensation and Recovery Research, Monash University. It contains caselevel administrative data received from the VWA, including data on industry, occupation, employer, workplace, demographics, injury, health care services, payments and medical certificates. ${ }^{16}$ Ethics approval was obtained from the Monash University Human Research Ethics Committee.

\section{Inclusion and exclusion}

Medical certificate data were not routinely captured by the VWA before 1 January 2003. At the time of analysis, the database contained complete information for all workers compensation claims up to 31 December 2010. All data for accepted compensation claims lodged by working age adults (15 to 65 years) with a date of injury or illness between 1 January 2003 and 31 December 2010 were extracted. Claims were then excluded if: they were for health care expenses only (ie, income replacement benefits were not paid); the initial medical certificate was written by a health practitioner other than a GP; or the information contained errors in logic (eg, date of certificate issue preceded date of injury).

\section{Statistical analysis}

Certificates were organised into three predefined types: complete absence from work recommended (unfit for work); RTW with alternative duties (eg, modified duties) recommended; and full RTW recommended (fit for work).

The VWA uses the national Type of Occurrence Classification System (TOOCS) Third Edition ${ }^{17}$ to code injury and illness types. Following several consultations with GPs, TOOCS groups were mapped onto six injury and illness categories (Appendix 1; online at mja.com.au).

Rates of certification were calculated for each injury and illness category and type of certificate. The numbers of certificates issued were divided by the number of full-time workers in the state in the 2006-07 financial year (about 1.79 million). ${ }^{15}$ This year was chosen as it was the midpoint of the study period. Rates are presented per 1000 workers with 95\% confidence intervals.

Descriptive statistics were used to analyse the data. Analyses of variance and $\chi^{2}$ tests for independence were used to examine differences between medical certificates across injury and illness categories. Kruskal-Wallis and Mann-Whitney $U$ tests were used to compare certificate duration between groups. Post-hoc tests were used to evaluate pairwise differences between injury and illness categories for each type of certificate. Type 1 errors were controlled using the Bonferroni approach, setting the level of significance to $P=0.0033$. SPSS version 20.0 (IBM) was used for all analyses.

\section{Results}

Of 207949 accepted compensation claims that we extracted, 83607 were excluded; 78086 were for health care expenses only, 5439 had an initial medical certificate not written by a GP, and 82 contained errors in logic. Over the study period, initial medical certificates were issued by 9750 GPs to 124424 workers.

The numbers of initial medical certificates issued and rates of certification, by certificate type and injury and illness category, are shown in Box 1. The largest proportion of certificates was for musculoskeletal injuries and diseases $(40.2 \%)$, followed by back pain and strains $(16.4 \%)$ and other traumatic injuries (15.6\%). The majority of certificates $(74.1 \%)$ recommended that workers were unfit for work, $22.8 \%$ recommended alternative duties and $3.1 \%$ recommended that workers were fit for work. Men received more certificates in all injury and illness categories except the 
2 Duration of initial medical certificates for workers compensation claims, by certificate type and injury and illness category, Victoria, 2003-2010*

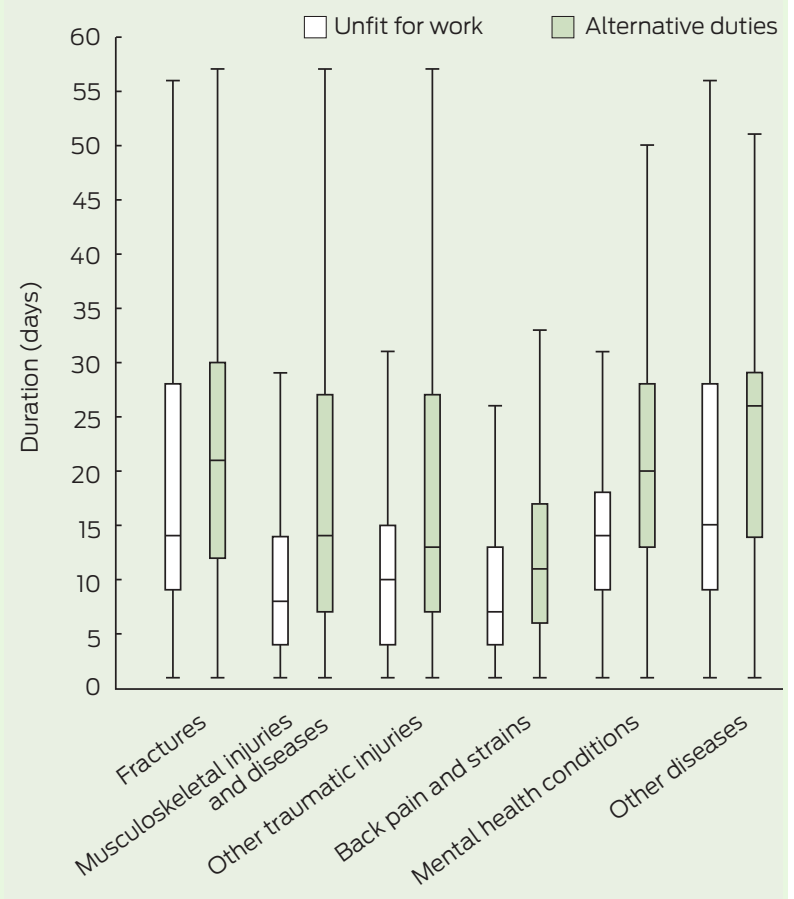

* Horizontal lines represent median values; lower and upper limits of the vertical bars represent 1st and 3rd quartiles, respectively; and error bars represent $95 \% \mathrm{Cls}$. with the highest proportion of certificates recommending alternative duties was other diseases (39.9\%), followed by musculoskeletal injuries and diseases and back pain and strains. There were relatively small proportions of certificates recommending that workers were fit for work across all injury and illness categories.

There were significant differences in types of certificates issued in all injury and illness categories $\left(\chi^{2}=\right.$ 6759.6, $\mathrm{df}=10, n=124424, P<0.001)$. Post-hoc comparisons revealed that there were also significant differences between all pairs of injury and illness categories, except for fractures versus other traumatic injuries.

\section{Initial medical certificate duration}

The median and first and third quartile values for initial medical certificate duration by certificate type and injury and illness category are shown in Box 2. Alternative-duties certificates were significantly longer in duration than unfit-for-work certificates in all injury and illness categories $\left(\chi^{2}=62.44, \mathrm{df}=1\right.$, $n=120509, \quad P<0.001)$. However, duration varied between the categories; for example, certificates issued to workers with musculoskeletal injuries and diseases, back pain and strains and other traumatic injuries were of lesser median duration than those issued to workers with fractures, MHCs and other diseases.

For unfit-for-work certificates, no significant difference in duration was found between the musculoskeletal injuries and diseases and other traumatic injuries categories $(U=$ 258904876.0, $Z=-2.27, P=0.02)$. All other differences were statistically significant. For alternative-duties certificates, differences in duration were significant between all categories, except fractures versus MHCs $(U=$ 614869.0, $Z=-0.64, P=0.52)$, fractures versus other diseases $(U=3880869, Z=$ $-1.71, P=0.08)$ and other diseases versus MHCs $(U=1113018.0, Z=-2.46$, $P=0.01$ ).

\section{Subsequent medical certificates}

The numbers of subsequent certificates issued, for claims that had an initial certificate issued by a GP, and duration of these certificates are shown in Box 3. Overall, 1660176 subsequent certificates were issued. Most commonly, they were for mus- culoskeletal injuries and diseases, followed by back pain and strains. There were no statistically significant differences between the duration of unfitfor-work and alternative-duties subsequent certificates. Some subsequent certificates were issued by health professionals other than GPs.

\section{Discussion}

From 2003 to 2010 in Victoria, more than $70 \%$ of initial medical certificates issued by GPs for injured and ill workers were unfit-for-work certificates, and fewer than a quarter recommended alternative duties. This is an important finding in the context of growing evidence regarding the health benefits of work, ${ }^{1,18}$ the importance of workforce participation for social and economic development, ${ }^{2}$ and the potential health and economic benefits of early RTW. ${ }^{3}$

The rate of sickness certification per 1000 workers varied substantially between injury and illness categories. The highest proportion of unfit-forwork certificates were written for workers with a MHC, followed by fractures, other traumatic injuries, back pain and strains, musculoskeletal injuries and diseases, and other diseases. Recent studies in the United Kingdom have also shown that GPs are more likely to issue unfit-for-work certificates for patients with MHCs than other conditions. ${ }^{9,10}$ Conversely, GPs in our study were more likely to certify workers with other diseases as suitable for alternative duties than those in other categories. Our data also show that the median duration of unfit-for-work certificates issued by GPs to patients with MHCs is longer than in patients with musculoskeletal injuries and diseases, back pain and other traumatic injuries.

There is a stigma associated with mental illness that may influence pursuit of workers compensation claims among workers with MHCs. ${ }^{19}$ Health professionals are more likely to perceive people with mental illness as having poorer health outcomes than they really have. ${ }^{20}$ There is often confusion about when a worker with a MHC should resume work, and workplace accommodations are often not in place to facilitate the RTW process. ${ }^{21}$ The ability of a workplace to accom- 
3 Numbers and duration of subsequent medical certificates issued to workers compensation claimants (where initial certificate was issued by a general practitioner), by certificate type and injury and illness category, Victoria, 2003-2010

\begin{tabular}{|c|c|c|c|c|c|c|c|}
\hline $\begin{array}{l}\text { Injury and illness } \\
\text { category }\end{array}$ & $\begin{array}{l}\text { No. of } \\
\text { claims* }\end{array}$ & $\begin{array}{c}\text { No. of certificates } \\
\text { (\% of all } \\
\text { certificates)* }\end{array}$ & $\begin{array}{l}\text { Mean (SD) } \\
\text { certificates } \\
\text { per claim* }\end{array}$ & $\begin{array}{l}\text { No. of unfit-for-work } \\
\text { certificates } \\
\text { (\% within category) }\end{array}$ & $\begin{array}{l}\text { No. of alternative- } \\
\text { duties certificates } \\
\text { (\% within category) }\end{array}$ & $\begin{array}{l}\text { Median (1st-3rd } \\
\text { quartile) duration } \\
\text { of unfit-for-work } \\
\text { certificates, days }\end{array}$ & $\begin{array}{l}\text { Median (1st-3rd } \\
\text { quartile) duration of } \\
\text { alternative-duties } \\
\text { certificates, days }\end{array}$ \\
\hline Fractures & 12102 & $106115(6.4 \%)$ & $8.7(12.5)$ & $53578(50.5 \%)$ & $46863(44.2 \%)$ & $28(15-29)$ & $28(21-29)$ \\
\hline $\begin{array}{l}\text { Musculoskeletal injuries } \\
\text { and diseases }\end{array}$ & 50052 & $765181(46.1 \%)$ & $15.3(17.1)$ & $348558(45.6 \%)$ & $388624(50.8 \%)$ & $27(14-28)$ & $28(18-29)$ \\
\hline Other traumatic injuries & 19467 & $170754(10.3 \%)$ & $8.7(13.5)$ & 86342 (50.6\%) & $75112(44.0 \%)$ & $23(9-28)$ & $27(14-28)$ \\
\hline Back pain and strains & 20388 & $349278(21.0 \%)$ & $17.1(18.9)$ & $165188(47.3 \%)$ & $172252(49.3 \%)$ & $27(10-28)$ & $27(14-28)$ \\
\hline Mental health conditions & 12663 & $190842(11.5 \%)$ & $15.1(16.5)$ & $124751(65.4 \%)$ & 60909 (31.9\%) & $28(26-29)$ & $28(27-29)$ \\
\hline Other diseases & 9752 & $78006(4.7 \%)$ & 7.9 (11.9) & $37863(48.5 \%)$ & $35984(46.1 \%)$ & $27(14-28)$ & $28(20-29)$ \\
\hline Total & 124424 & $1660176(100 \%)$ & $13.3(16.5)$ & $816280(49.2 \%)$ & $779744(47.0 \%)$ & $27(14-28)$ & $28(14-28)$ \\
\hline
\end{tabular}

modate an injured or ill worker may influence GP certification behaviour.

We also found substantial sex differences. Women with MHCs were more likely to receive certificates than men, but men received a greater proportion of certificates in all other categories. This is consistent with previous findings showing that women have a proportionately greater burden of sickness absence due to mental illness ${ }^{22}$ and that women are more susceptible to depression as a result of job stress than men. ${ }^{23}$

Our data were obtained from a population-based database of injured and ill workers across a diverse range of industries and occupations, and included GPs operating in a diverse range of health care practices. The six categories of injury and illness that we used were derived from a national standard occupational injury classification system. ${ }^{17}$ To maintain maximum data retention across types of injury and illness, it was necessary to group diverse conditions in some categories, while other categories represented more homogenous clinical populations. Within the more heterogenous categories, there may be wide ranges of expected recovery and RTW trajectories for different conditions. Also, workers compensation data do not include cases where an injured or ill worker does not file a compensation claim. Such cases account for about $23 \%$ of work-related conditions for which patients attend Australian GP practices, ${ }^{19}$ so this study does not represent a complete picture of GP certification practices.

Our study is the first to assess sickness certification of injured and ill workers in Australia, and the first to assess certification by GPs in a population as large as the Victorian population of full-time workers. It provides a foundation for comparison with other jurisdictions and health care systems, and a benchmark against which future public health initiatives aimed at modifying GP certification behaviour can be evaluated.

We identified substantial variation in GP practice depending on worker condition. Future research is needed to determine why rates of alternativeduties and fit-for-work certificates among workers with MHCs are less than those for workers with other conditions. It is possible that differences in certification behaviour are due to severity of injury, workplace conditions (eg, lack of appropriate modified duties), challenges in dealing with mental health claims and other factors.

\section{Competing interests: No relevant disclosures.}

Received 21 Apr 2013, accepted 12 Jul 2013.

1 Waddell G, Burton AK. Is work good for health and well being? London: TSO, 2006.

2 BlackC. Working for a healthier tomorrow: review of the health of Britain's working age population. London: TSO, 2008.

3 Rueda S, Chambers L, Wilson M, et al. Association of returning to work with better health in working-aged adults: a systematic review. Am J Public Health 2012; 102: 541-556.

4 Franche RL, Cullen K, Clarke J, et al. Workplacebased return-to-work interventions: a systematic review of the quantitative literature. J Occup Rehabil 2005; 15: 607-631.

5 Hann M, Sibbald B. General practitioners' attitudes towards patients' health and work. Final Report for Health Work and Well-being Delivery Unit. London: Department for Work and Pensions, 2011.

6 Mowlam A, Lewis J. Exploring how general practitioners work with patients on sick leave. Leeds: Department for Work and Pensions, 2005.

7 Cohen DA, Aylward M, Rollnick S. Inside the fitness for work consultation: a qualitative study. Occup Med (Lond) 2009; 59: 347-352.
8 Hiscock J, Ritchie J. The role of GPs in sickness certification. London: Department for Work and Pensions, 2001.

9 Campbell A, Ogden J. Why do doctors issue sick notes? An experimental questionnaire study in primary care. Fam Pract 2006; 23: 125-130.

10 Wynne-Jones G, Mallen CD, Mottram S, et al. Identification of UK sickness certification rates, standardised for age and sex. Br J Gen Pract 2009; 59: 510-516.

11 Shiels C, Gabbay MB, Ford FM. Patient factors associated with duration of certified sickness absence and transition to long-term incapacity. Br J Gen Pract 2004; 54: 86-91.

12 Cohen D, Marfell N, Webb K, et al. Managing longterm worklessness in primary care: a focus group study. Occup Med (Lond) 2010; 60: 121-126.

13 Hussey S, Hoddinott P, Wilson P, et al. Sickness certification system in the United Kingdom: qualitative study of views of general practitioners in Scotland. BMJ 2004; 328: 88.

14 Kosny A, Franche RL, Pole J, et al. Early healthcare provider communication with patients and their workplace following a lost-time claim for an occupational musculoskeletal injury. J Occup Rehabil 2006; 16: 27-39.

15 Australian Bureau of Statistics. Labour force, Australia. Canberra: ABS, 2013. (ABS Cat. No. 6202.0.)

16 Ruseckaite R, Collie A. Repeat workers' compensation claims: risk factors, costs and work disability. BMC Public Health 2011; 11: 492

17 National Occupational Health and Safety Commission. Type of Occurrence Classification System. 3rd ed. Canberra: Safe Work Australia, 2004.

18 Australasian Faculty of Occupational and Environmental Medicine. Australian and New Zealand consensus statement on the health benefits of work. Sydney: Royal Australian College of Physicians, 2011.

19 Collie A, Pan Y, Britt H, Henderson J. Coverage of work-related injury and disease in general practice. Int J Soc Sec Workers Comp 2011; 3: 1-11.

20 Jorm AF, Korten AE, Jacomb PA, et al. Attitudes towards people with a mental disorder: a survey of the Australian public and health professionals Aust N Z J Psychiatry 1999; 33: 77-83.

21 Andersen MF, Neilsen KM, Brinkmann S. Metasynthesis of qualitative research on return to work among employees with common mental disorders. Scand J Work Environ Health 2012; 38: 93-104.

22 Koopmans PC, Bültmann U, Roelen CA, et al. Recurrence of sickness absence due to common mental disorders. Int Arch Occup Environ Health 2011; 84:193-201.

23 LaMontagne A, Keegel T, Vallance D, et al. Job strain - attributable depression in a sample of working Australians: assessing the contribution to health inequalities. BMC Public Health 2008; 8: 181 